University of Nebraska - Lincoln

DigitalCommons@University of Nebraska - Lincoln

\title{
Recycled Paper Products as Substitutes for Gelling Agent in Screwworm (Diptera: Calliphoridae) Larval Diet
}

M. F. Chaudhury

USDA-ARS

L. Alfredo Alvarez

USDA-ARS

L. Lopez Velazquez

USDA-ARS

Follow this and additional works at: https://digitalcommons.unl.edu/usdaarsfacpub

Part of the Agricultural Science Commons

Chaudhury, M. F.; Alvarez, L. Alfredo; and Velazquez, L. Lopez, "Recycled Paper Products as Substitutes for Gelling Agent in Screwworm (Diptera: Calliphoridae) Larval Diet" (2002). Publications from USDA-ARS / UNL Faculty. 323.

https://digitalcommons.unl.edu/usdaarsfacpub/323

This Article is brought to you for free and open access by the U.S. Department of Agriculture: Agricultural Research Service, Lincoln, Nebraska at DigitalCommons@University of Nebraska - Lincoln. It has been accepted for inclusion in Publications from USDA-ARS / UNL Faculty by an authorized administrator of DigitalCommons@University of Nebraska - Lincoln. 


\title{
Recycled Paper Products as Substitutes for Gelling Agent in Screwworm (Diptera: Calliphoridae) Larval Diet
}

\author{
M. F. CHAUDHURY, ${ }^{1}$ L. ALFREDO ALVAREZ, AND L. LOPEZ VELAZQUEZ \\ Screwworm Research Unit, USDA-ARS, Apartado 544, Tuxtla Gutierrez, Chiapas, Mexico
}

\begin{abstract}
J. Econ. Entomol. 95(6): 1337-1341 (2002)
ABSTRACT Absorbent recycled paper products were tested and compared with a sodium polyacrylate gelling agent, Aquatain, for solidifying larval diets of the screwworm, Cochliomyia hominivorax (Coquerel). A recycled newsprint product, Terra-Mulch, when mixed with water and dietary ingredients produced a diet medium of homogeneous texture that supported larval growth and development comparable to the standard diet prepared with the gelling agent. Biological yields as calculated from number of pupae per tray from both the diets were similar. Three other types of recycled paper products were tested. Although less homogeneous in texture, these diets were as good as the diet with Terra-Mulch. There were no significant differences in the mean larval and pupal weights, no. of pupae/tray, percent emergence, oviposition, percent hatch, and percent longevity. When tests were conducted through eight consecutive generations, no adverse effect was noticed in any of the life history parameters. Terra-Mulch is inexpensive and biodegradable compared with the gelling agent Aquatain that is expensive and not biodegradable. Replacing Aquatain with Terra-Mulch in the screwworm larval diet for mass rearing may result in an annual savings of more than half a million U.S. dollars in costs of material and labor.
\end{abstract}

KEY WORDS screwworm, larval diet, mass, rearing, recycled paper

MASS REARING OF SCREWWORM, Cochliomyia hominivorax (Coquerel), for the screwworm eradication project of the United States Department of Agriculture in collaboration with the government of Mexico is one of the largest insect rearing programs in the world. The mass production facility, located in Chiapa de Corzo, Chiapas, Mexico, currently produces $\approx 120$ million flies per week. Nearly $25,000 \mathrm{~kg}$ of dry food at a cost of about U.S. $\$ 40,000$ per week is required for this purpose. Most of the cost and the labor needed for screwworm mass production is dedicated to larval rearing. For this purpose, over 20,000 liters of larval diet are prepared daily. The larval diet that is currently used for mass rearing is slightly modified from Taylor et al. (1991), and consists of $6 \%$ spray dried whole bovine blood, $4 \%$ inedible egg product, $4 \%$ milk substitute, a milk protein + soya protein product, and $1.8 \%$ gelling agent, Aquatain, mixed with $0.1 \%$ formalin and $84.1 \%$ water.

The gelling agent is used to solidify the liquid rearing medium previously used for mass rearing of screwworm larvae, and does not have any nutritional value. Harris et al. $(1984,1985)$ tested several gelling com-

This article reports the results of research only. Mention of a proprietary product does not constitute an endorsement or a recommendation by the USDA for its use.

${ }^{1}$ Current address: USDA-ARS, Midwest Livestock Insects Res. Unit, 305 P.I. Bldg. UN-L East Campus, Lincoln, NE 68583-0938 (e-mail: mchaudhury2@unl.edu). pounds to solidify the larval rearing medium. Among these compounds, the gelling agent Water-Lock G-400, was found most suitable and was later used in the larval diet for mass rearing for a number of years (Taylor and Mangan 1987, Taylor et al. 1991). WaterLock is a hydrophilic sodium polyacrilonitrile polymer that acts as an absorbent. The consistency of the diet mixed with Water-Lock remains relatively constant over a wide range of humidity; the diet remains semisolid, emits little odor, and is acceptable to screwworm larvae for a longer time before becoming contaminated by toxic waste products (Taylor 1988). When compared with previously used standard liquid rearing medium, the Water-Lock rearing system yielded $2 \%$ heavier pupae, $32 \%$ higher egg-to-pupa survival, and required $54 \%$ less diet and $88 \%$ less labor cost (Taylor et al. 1991).

Water-Lock G-400 is expensive (U.S. $\$ 8.25 / \mathrm{kg}$ ) and nonbiodegradable. Therefore, use of other cheaper gelling agents for screwworm diet was investigated (Chaudhury and Alverez 1999). For screwworm mass rearing, a similar polyacrilate gel, Aquatain, has recently replaced Water-Lock. Although less expensive (U.S. $\$ 5.00 / \mathrm{kg}$ ), Aquatain is also not biodegradable, and therefore, may accumulate in the environment. Consequently, an absorbent suitable for use in the screwworm larval diet, which is biodegradable, less costly, and readily available, would be most desirable. 
The current study investigated the suitability of various absorbent recycled paper products for the larval diet in comparison to the gelled diet with respect to larval wt, pupal wt, number of pupae, adult emergence, fecundity, fertility, and adult longevity.

\section{Materials and Methods}

The recycled newsprint product, called TerraMulch, was obtained from Profile Product LLC, Buffalo Grove, IL, clean newsprint was purchased locally from a newsprint supplier (Proveedora Grafica de Chiapas, Chiapas, Mexico), and the gel Aquatain was purchased from Pioneer Medical Inc., Lakeland, FL. The other paper products included local used newspapers and locally produced used highly absorbent egg packaging materials. The clean newsprint, local newspapers, and the egg cartons were finely shredded using a paper shredder and a paper guillotine. TerraMulch, normally used as mulch in hydro seeding projects, was received from the factory as a preshredded and pulverized product. Three dietary ingredients, i.e., spray dried whole blood and spray dried egg product, were purchased from California Spray Dry Co., Stockton, CA, and the dry milk substitute from the Purina Mexico, Puebla, Mexico. Tests were conducted on the Panama-95 strain of screwworm developed by ARS from Panama screwworm flies collected in 1995 (Chaudhury et al. 2002).

Diets with paper products were prepared by mixing $6 \mathrm{~g}$ of one of the products with $79.9 \mathrm{ml}$ warm water $\left(37.5 \pm 0.5^{\circ} \mathrm{C}\right)$ and $0.1 \mathrm{ml}$ formalin and thoroughly blending in a blender (3-5 $\mathrm{min})$, and then adding and hand-mixing ( $2 \mathrm{~min}) 6 \mathrm{~g}$ spray dried blood, $4 \mathrm{~g}$ spray dried egg, and $4 \mathrm{~g}$ milk substitute to yield $100 \mathrm{ml}$ diet. The gel diet was prepared by mixing the same amounts of dietary ingredients with $1.8 \mathrm{~g}$ of Aquatain and then adding $84.2 \mathrm{ml}$ warm water mixed with $0.1 \mathrm{ml}$ formalin to the dry ingredients to make $100 \mathrm{ml}$ of the diet. The gel diet was hand-mixed in a plastic container for 5 min. The final temperature and $\mathrm{pH}$ of each of the mixed diets were recorded to ascertain that the variations in these physical properties were negligible among the groups of diets prepared. Insect rearing and the measurements of parameters were carried out according to Chaudhury et al. (1998) with some modifications as detailed under the experimental procedures below.

Experiment 1. These tests were conducted to compare a diet with the recycled newsprint product, Terra-Mulch, with a gelled diet, in terms of larval weight, pupal weight, number of pupae and yield. Batches of 375 or $500 \mathrm{mg}$ of eggs $(\approx 7,500$ or 10,000 eggs, respectively) were placed on $5 \times 5 \mathrm{~cm}$ moistened paper towel on top of one liter of the prepared diet in separate plastic trays $(45 \times 35 \times 6 \mathrm{~cm})$ in the larval rearing room $\left(39 \pm 1^{\circ} \mathrm{C}\right)$. The control (gel) diet trays received only $500 \mathrm{mg}$ eggs per tray. On the following day (day 1 ) the newly hatched larvae crawled off the paper towel into the diet. On day 2 and 3, another 2.5 and 4 liters of freshly prepared diet, respectively, was added to each tray. On day 4 the trays were placed inside larger trays $(64 \times 45 \times 6 \mathrm{~cm})$ with $2 \mathrm{~cm}$ of sawdust in the bottom of the large tray. Mature (third instar) larvae crawled out of the media on day 5 and fell into the sawdust where pupation occurred. A sample of 100 larvae were taken randomly before pupation from each tray and weighed. Five days after pupation, pupae were sifted from the sawdust and weighed. Also, a sample of 100 pupae was taken randomly from each tray and weighed; from the two weights, total number of pupae in each container was determined. Percent yield was determined by dividing the number of pupae obtained by the number of pupae expected $(7,500$ or 10,000 for 375 or $500 \mathrm{~g}$ of eggs/tray, respectively) and multiplying by 100 . Tests were replicated $6 \times$ with 11 trays/replicate.

Experiment 2. These tests were conducted to compare several life history parameters (larval and pupal weights, number of pupae, percent emergence, oviposition, percent egg hatch, and adult longevity) of screwworm reared on diet with Terra-Mulch, and other diets containing shredded newspaper, shredded egg cartons, and shredded clean (unprinted) newsprint. These tests were conducted for eight consecutive generations. Essentially, the tests were conducted according to the procedures reported by Chaudhury et al. (1999). One hundred milligrams of eggs $(\approx 2000$ eggs) were placed on moist paper towel $(3 \times 3 \mathrm{~cm})$ above $300 \mathrm{ml}$ of diet in a small plastic tray $(25.5 \times$ $18.5 \times 9.5 \mathrm{~cm}$ deep) and placed in the larval rearing room $\left(39 \pm 1{ }^{\circ} \mathrm{C}\right)$. On the following day the eggs hatched. The developing larvae received additional 300 and $600 \mathrm{ml}$ of fresh diet on the top of the old media 48 and $72 \mathrm{~h}$ after hatching, respectively. Before the mature larvae were ready to crawl out of the media, the diet tray with the developing larvae was placed inside a larger plastic tray $(28 \times 24 \times 13 \mathrm{~cm}$ deep $)$ with $2 \mathrm{~cm}$ of sawdust in the bottom. Mature larvae crawled out of the media and pupated in the sawdust in the bottom tray. Immediately after the larvae dropped into the bottom tray, 100 larvae were selected randomly from each tray and weighed. After $5 \mathrm{~d}$, pupae were sifted from the sawdust and weighed. Also, a sample of 100 pupae was taken randomly from each tray and weighed; from the two weights, the total number of pupae in each tray was determined. One hundred pupae from each tray were held in small cages and allowed to emerge and percent emergence were recorded. Longevity was determined by holding newly emerged flies in cages with honey and water and recording their mortality until $50 \%$ of the flies survived. To determine fecundity, 500 females from each test were held in a cage with a diet of honey mixed with spray dried egg (Chaudhury et al. 2000) and water. When the females were $7 \mathrm{~d}$ old, a petri dish with $5 \mathrm{~g}$ of horsemeat was introduced into the cage to induce oviposition. After allowing $2 \mathrm{~h}$ for oviposition, the petri dish was removed from the cage and the egg batches were collected and weighed. To determine fertility, two samples of $100 \mathrm{mg}$ of eggs from each test were placed in petri dishes lined with moist filter paper and containing $5 \mathrm{~g}$ of horsemeat and incubated at $38 \pm 1^{\circ} \mathrm{C}$ for $20 \pm 2 \mathrm{~h}$. Unhatched 
Table 1. Life history parameters (mean \pm SD) of screwworm reared on diets prepared with recycled newsprint Terra-Mulch and the control diet with gel Aquatain

\begin{tabular}{lccc}
\hline \hline \multicolumn{1}{c}{$\begin{array}{c}\text { Parameters } \\
(F ; P)\end{array}$} & $\begin{array}{c}\text { Diet with Terra-Mulch } \\
375 \mathrm{mg} \text { eggs/tray }\end{array}$ & $\begin{array}{c}\text { Diet with Terra-Mulch } \\
500 \mathrm{mg} \text { eggs } / \text { tray }\end{array}$ & $\begin{array}{c}\text { Diet with gel (control) } \\
500 \mathrm{mg} \text { eggs/tray }\end{array}$ \\
\hline Larval wt, mg $\left(27.8^{*} ; 0.000\right)$ & $70.82 \pm 3.64 \mathrm{a}$ & $61.67 \pm 2.11 \mathrm{~b}$ & $59.89 \pm 2.79 \mathrm{~b}$ \\
Pupal wt, mg $\left(16.5^{*} ; 0.000\right)$ & $53.82 \pm 2.48 \mathrm{a}$ & $47.44 \pm 1.9 \mathrm{~b}$ & $45.85 \pm 2.77 \mathrm{~b}$ \\
No. Pupae/tray $\left(15.1^{*} ; 0.001\right)$ & $6877 \pm 960 \mathrm{a}$ & $9875 \pm 903 \mathrm{~b}$ & $8798 \pm 1182 \mathrm{~b}$ \\
\% Biological yield $(1.61 ; 0.247)$ & $91.69 \pm 12$ & $98.75 \pm 9$ & $87.98 \pm 11$ \\
\hline
\end{tabular}

Mean \pm SD, means for each parameter followed by different letters are significantly different by Tukey's range test after a significant $F$ value (df, $2 ; P=0.05)$.

eggs and eggshells from each petri dish were collected, counted under microscope, and percent hatch determined.

Statistics. Data were statistically evaluated with analysis of variance (ANOVA) using complete randomized block design followed by a Tukey's multiple range test to separate means after a significant $F$ value (Sokal and Rohlf 1981, NCSS 2000). Also, correlation analysis and subsequent $t$-test for significance were performed to see if there was a generation effect on the parameters recorded for the diets with paper products.

\section{Results}

Experiment 1. Four life history parameters-larval weight, pupal weight, number of pupae, and percent biological yield-were compared. Means and standard deviations of these life stages resulting from larvae reared on two diets containing Terra-Mulch and a control diet with the standard Aquatain gel are presented in Table 1. Larval and pupal weights obtained from the diet with Terra-Mulch seeded with $375 \mathrm{mg}$ of eggs were significantly higher that those obtained from the diet with Terra-Mulch seeded with $500 \mathrm{mg}$ of eggs, as well as the control diet, with $500 \mathrm{mg}$ of eggs. The number of pupae per tray was significantly lower from the diet with Terra-Mulch seeded with $375 \mathrm{mg}$ of eggs than those from the same diet seeded with $500 \mathrm{mg}$ of eggs and the control diet with $500 \mathrm{mg}$ of eggs. Percent biological yield for the two diets with TerraMulch were higher than that of the control, though not significantly so (Table 1 ).

Experiment 2. Seven life history parameters, i.e., larval weight, pupal weight, number of pupae, percent emergence, oviposition, percent egg hatch, and adult longevity were analyzed. Means and standard devia- tions of these parameters from screwworm reared for eight generations on diets containing Terra-Mulch and three other types of recycled papers are presented in Tables 2 and 3. Results show that there was no significant difference between the diet with TerraMulch and those with other paper products in all the parameters examined (Table 2). Larvae developed equally well in all the diets and pupated normally. Pupal weight and number of pupae per tray were within an acceptable range in all respects. Adult emergence and longevity were normal in all the diets. Oviposition and percent hatch were also within the normal range of screwworm reproductive performance in the laboratory.

Results of the continuous rearing through eight consecutive generations with all four paper diets (Table 3) show normal larval growth and development through all the generations. Correlation analysis with subsequent $t$-test for significance show that there was no relationship between parameters examined and generations, indicating that the diets did not have a deteriorating effect on the larval growth and development and the subsequent life stages during eight consecutive generations. ANOVA with complete randomized block design yielded significant $F$ values for oviposition, percent hatch and percent emergence (Table 3). Oviposition was significantly lower in the second generation when comparing with oviposition in the fifth generation. Percent hatch was significantly lower in eighth generation when comparing with egg hatch in the fourth generation. Percent emergence was significantly lower in the seventh generation when comparing emergence in the other generations. For larval and pupal weights, number of pupae per tray, and adult longevity, there were no significant differences among generations.

Table 2. Comparison of life history parameters (mean \pm SD) of screwworm reared on diets with recycled paper products

\begin{tabular}{|c|c|c|c|c|}
\hline Parameters $(F ; P)$ & Terra-Mulch & Newspaper & Egg carton & Newsprint (clean) \\
\hline Larval wt, mg $(0.2 ; 0.897)$ & $62.9 \pm 3.0$ & $62.5 \pm 3.0$ & $63.4 \pm 6.2$ & $62.0 \pm 4.6$ \\
\hline Pupal wt, mg $(0.15 ; 0.927)$ & $47.8 \pm 2.3$ & $47.6 \pm 2.6$ & $48.0 \pm 4.0$ & $47.0 \pm 3.8$ \\
\hline No. pupae/tray $(1.53 ; 0.235)$ & $1240 \pm 298$ & $1551 \pm 270$ & $1525 \pm 307$ & $1411 \pm 457$ \\
\hline$\%$ emergence $(2.45 ; 0.092)$ & $92.5 \pm 4.3$ & $94.9 \pm 2.9$ & $95.3 \pm 3.5$ & $93.2 \pm 2.6$ \\
\hline Eggs laid, g $(0.13 ; 0.942)$ & $3.9 \pm 1.6$ & $4.2 \pm 0.7$ & $4.0 \pm 1.5$ & $4.1 \pm 0.6$ \\
\hline$\%$ egg hatch $(0.26 ; 0.852)$ & $81.3 \pm 7.7$ & $78.3 \pm 15.1$ & $82.7 \pm 10.3$ & $81.0 \pm 13.1$ \\
\hline Longevity, d) $(0.11 ; 0.952)$ & $18.5 \pm 1.4$ & $18.1 \pm 1.6$ & $18.4 \pm 1.8$ & $18.5 \pm 2.1$ \\
\hline
\end{tabular}

Mean $\pm \mathrm{SD}$ in each parameter are not significantly different from each other $(\mathrm{df}=3 ; P=0.05$, Tukey's multiple range test $)$. 
Table 3. Comparison of life history parameters (mean \pm SD) of screwworm reared through 8 consecutive generations on diets with recycled paper products

\begin{tabular}{|c|c|c|c|c|c|c|c|c|c|c|c|}
\hline \multirow{2}{*}{ Parameters } & \multicolumn{2}{|c|}{ Correlation } & \multirow{2}{*}{$F$-ratio } & \multicolumn{8}{|c|}{ Generation } \\
\hline & $r$ & $t$ & & 1 & 2 & 3 & 4 & 5 & 6 & 7 & 8 \\
\hline Larval wt, mg & 0.5 & 1.5 & 28 & $62.0 \pm 3.2$ & $59.4 \pm 3.3$ & $65.7 \pm 3.3$ & $60.8 \pm 4.1$ & $59.2 \pm 3.9$ & $63.3 \pm 3.7$ & $54.5 \pm 2.7$ & $67.1 \pm 4.6$ \\
\hline Pupa & 0.2 & 0.6 & 1 & $48.2 \pm 2.6$ & $45.4 \pm 3.0$ & $50.3 \pm$ & $46.0 \pm 3.0$ & $45.9 \pm 3.4$ & $47.2 \pm 2.7$ & $47.5 \pm 3.1$ & $50.4 \pm 3.3$ \\
\hline No. pupae/tray & 0.7 & 2.4 & 1.46 & $1540 \pm 405$ & $1587 \pm 108$ & $1367 \pm 538$ & $1684 \pm 184$ & $1602 \pm 208$ & $1238 \pm 282$ & $1281 \pm 383$ & $1159 \pm 349$ \\
\hline$\%$ emergence & 0.3 & 0.9 & $4.77^{*}$ & $94 \pm 2 \mathrm{a}$ & $94 \pm 1 \mathrm{a}$ & $96 \pm 2 \mathrm{a}$ & $96 \pm 2 a$ & $95 \pm 3 a$ & $95 \pm 4 a$ & $88 \pm 3 b$ & $95 \pm 3 a$ \\
\hline Eggs & 0.3 & 0.7 & 2 & $4.5 \pm 0.5 \mathrm{ab}$ & $2.2 \pm 1.9 \mathrm{a}$ & $3.6 \pm 0.9 \mathrm{ab}$ & $4.8 \pm 0.4 \mathrm{~b}$ & $4.8 \pm 0.4 \mathrm{~b}$ & $4.3 \pm 1.4 \mathrm{ab}$ & $4.2 \pm 0.5 \mathrm{ab}$ & $3.8 \pm 0.5 \mathrm{ab}$ \\
\hline$\%$ es & 0.6 & 2.2 & * & $86 \pm 6 \mathrm{ab}$ & $84 \pm 10 \mathrm{ab}$ & $84 \pm 7 \mathrm{ab}$ & $94 \pm 6 \mathrm{a}$ & $77 \pm 8 \mathrm{ab}$ & $72 \pm 16 \mathrm{ab}$ & $82 \pm 5 \mathrm{ab}$ & $68 \pm 11 b$ \\
\hline Longevity, d & 0.4 & 1.3 & 2.31 & $18.3 \pm 1$ & $16.5 \pm 1.3$ & $17.0 \pm 1.2$ & $19.8 \pm 1.3$ & $19.5 \pm 1.3$ & $18.5 \pm 2.1$ & $19.0 \pm 0.8$ & $18.5 \pm 1.3$ \\
\hline
\end{tabular}

$*$ Mean \pm SD in each parameter followed by different letters are significantly different from each other $(\mathrm{df}=7 ; P=0.05$, Tukey's multiple range test). For $t$-test $(\mathrm{df}=7)$ following correlation analysis, means in each parameter showed no difference.

\section{Discussion}

Results of this investigation indicate that the recycled absorbent paper products have potential for use in the screwworm larval diet and can effectively replace the gelling agent, Aquatain, currently being used. The diet with recycled newsprint product TerraMulch produced larvae and pupae as large or larger than those produced by the diet with Aquatain, indicating normal larval growth and development in the diet with the paper product. The standard procedure for mass rearing uses $1 \mathrm{~g}$ of eggs per tray of 15 liter diet (66.67 mg/liter diet). Our control and test with $500 \mathrm{mg}$ of eggs / 7.5 liter tray was of equivalent ratio to the mass rearing procedure. Although using $25 \%$ less amount of eggs (375 mg/ 7.5 liter tray), decreased the number of larvae per tray, it significantly increased the larval and pupal weight when compared with those obtained using $500 \mathrm{mg}$ eggs per tray (Table 1). This indicates that we have to use $<66.67 \mathrm{mg}$ of eggs/liter of diet if we want to get larger than $50 \mathrm{mg}$ pupa. The fact that the percent biological yield from the Terra-Mulch diet was not significantly different than that from the gelled diet, clearly indicates that the larvae survived equally well in diets with the paper product and the standard gelled diet.

When tests were conducted by substituting imported Terra-Mulch with locally available absorbent paper products, newspaper, egg cartons, and clean newsprint, these materials were found as suitable as the Terra-Mulch, although the texture of the diet with these other paper products was not as homogeneous as those with Terra-Mulch. No long-term adverse effect of the paper-based diets was noticed in any of the parameters when rearing was conducted through eight consecutive generations. Paper-based diets tended to be more porous than the gelled diet, thereby allowing the larvae more accessibility and ease of mobility. Furthermore, the physical texture of the diet indicates that the dietary ingredients in the gelled diet remain adsorbed tightly in the gel, causing some difficulty in larval feeding, whereas, the dietary ingredients in paper diets remain suspended in a thick slurry, and are easily available to the larvae. These physical properties of the diets also suggest that the gelled diet, after larval maturation, is probably discarded with some unused dietary ingredients. It is possible that, a paper-based diet may require less dietary ingredients for adequate larval growth and development.

Terra-Mulch was easier to handle and use, and needed no further processing, whereas the other three paper materials needed to be processed before using. The clean newsprint was bought from a local supplier and was expensive (U.S.\$2.10/ kg) when compared with Terra-Mulch (U.S. $\$ 0.30 / \mathrm{kg}$ ). Local newspaper and egg carton were obtained as recycled materials and no price for these products could be determined. Aquatain gelling agent presently costs U.S. $\$ 5.00 / \mathrm{kg}$. Replacing Aquatain by the recycled Terra-Mulch will result in a savings of more than U.S. $\$ 10,000$ weekly for rearing 150 million pupae, with an annual potential savings of over half a million dollars. Furthermore, the Terra-Mulch may be disposed of in a landfill without further processing, as is currently required for the Aquatain gel. This will further reduce the cost by eliminating labor and material costs for the disposal of the spent diet.

1. The United States Department of Agriculture prohibits discrimination in all its programs and activities on the basis of race, color, national origin, gender, religion, age, disability, political beliefs, sexual orientation, and marital or family status. (Not all prohibited bases apply to all programs.) Persons with disabilities who require alternative means for communication of program information (Braille, large print, audiotape, etc.) should contact USDA's TARGET Center at 202720-2600 (voice and TDD). To file a complaint of discrimination, write USDA, Director, Office of Civil Rights, Room 326-W, Whitten Building, $14^{\text {th }}$ and Independence Avenue, SW, Washington DC 20250-9410 or call 202-720-5964 (voice or TDD). USDA is an equal opportunity provider and employer.

2. The use of trade, firm, or corporation names in this publication is for information and convenience of the reader. Such use does not constitute an official endorsement or approval by the United States Department of Agriculture or the Agricultural Research Service of any product or service to the exclusion of others that may be suitable. 


\section{Acknowledgments}

We thank Donald L. Bailey (USDA-APHIS) and John B. Welch (USDA-ARS) for their suggestions and critical reading of the manuscript. Technical assistance of Celia Jiminez, Delfina Cruz, and Lupita Hernandez of USDA-ARS, Screwworm Research, Tuxtla Gutierrez, Mexico, is gratefully acknowledged.

\section{References Cited}

Chaudhury, M. F., L. A. Alvarez, and J. B. Welch. 1998. An alternative source of blood protein for screwworm (Diptera: Calliphoridae) larval diet. J. Econ. Entomol. 91: 1397-1400.

Chaudhury, M. F., and L. A. Alvarez. 1999. A new starchgrafted gelling agent for screwworm (Diptera: Calliphoridae) larval diet. J. Econ. Entomol. 92: 1138-1141.

Chaudhury, M. F., L. A. Alvarez, and L. L. Velazquez. 2000. A new meatless diet for adult screwworm (Diptera: Calliphoridae). J. Econ. Entomol. 93: 1398-1401.

Chaudhury, M. F., J. B. Welch, and L. A. Alvarez. 2002. Response of fertile and sterile screwworm (Diptera: Calliphoridae) flies to bovine blood inoculated with bacteria originating from screwworm-infested animal wounds. J. Med. Entomol. 39: 130-134.

Harris, R. L., R. D. Peterson, M. E. Vasquez-G., and O. H. Graham. 1984. Gelled media for the production of screwworm larvae. Southwest. Entomol. 9: 257-262.

Harris, R. L., E. F. Gersabeck, C. Corso, and O. H. Graham. 1985. Screwworm larval production on gelled media. Southwest. Entomol. 10: 253-256.

NCSS. 2000. NCSS Statistical System for Windows: User's manual, version 6. NCSS, Kaysville, UT.

Sokal, R. R., and F. J. Rohlf. 1981. Biometry. Freeman, New York.

Taylor, D. B. 1988. Comparison of two gelling agents for screwworm (Diptera: Calliphoridae) larval diet. J. Econ. Entomol. 81: 1414-1419.

Taylor, D. B., and R. L. Mangan. 1987. Comparison of gelled and meat diets for rearing screwworm, Cochliomyia hominivorax (Diptera: Calliphoridae) larvae. J. Econ. Entomol. 80:427-432.

Taylor, D. B., J. C. Bruce, and R. Garcia. 1991. Gelled diet for screwworm (Diptera: Calliphoridae) mass production. J. Econ. Entomol. 84: 927-935.

Received for publication 23 May 2002; accepted 9 August 2002 